九州大学学術情報リポジトリ

Kyushu University Institutional Repository

\title{
Lead-Alpha Ages of Some Granitic Rocks from North Kyushu and Central Japan
}

\section{Karakida, Yoshifumi}

Department of Geology, Faculty of Science, Kyushu University | Seinan Gakuin University

Tomita, Tôru

Department of Geology, Faculty of Science, Kyushu University | University of Electronics

Gottfried, David

U. S. Geological Survey

Stern, T.W.

U. S. Geological Survey

他

https://doi.org/10.5109/1543630

出版情報：九州大學理學部紀要：Series D, Geology. 16 (3)，pp.249-263，1965-11-20. Faculty of Science, Kyushu University

バージョン:

権利関係 : 


\title{
Lead-Alpha Ages of Some Granitic Rocks from North Kyushu and Central Japan
}

\author{
By
Yoshifumi Karakida, Tôru Tomita, David GotTFried, T. W. Stern, and H. J. Rose, Jr.

\begin{abstract}
Lead-alpha age determinations have been made on the accessory zircons and monazites of granitic rocks from the Fukuoka area, North Kyushu, and the eastern Aichi district and the Takato area, Central Japan. Six results for granitic rocks from the Fukuoka area range from 80 to $115 \mathrm{~m}$.y. with an average of $97 \mathrm{~m}$. y. Of these results, zircon and monazite from a single granite have the same age of $90 \mathrm{~m} . \mathrm{y}$. This good agreement between different minerals from the same rock indicates the reliability of the lead-alpha method. Four zircon ages and two monazite ages from the eastern Aichi district range from 70 to $105 \mathrm{~m}$. y. with an average of $90 \mathrm{~m}$.y. and nine zircon ages from the Takato area from 80 to $165 \mathrm{~m}$. y. with an average of $106 \mathrm{~m} . \mathrm{y}$.; of these ages, $165 \mathrm{~m}$. y. that is for the Takato quartz diorite engages the attention of the writers, because it is older than other granitic rocks in the same area. Since our results of age determinations are, though with a few exceptions, consistent with geological evidences and other isotopic ages, the granitic rocks from North Kyushu and the Ryoke belt in Central Japan are believed to be of Cretaceous age.
\end{abstract}

\section{Contents}

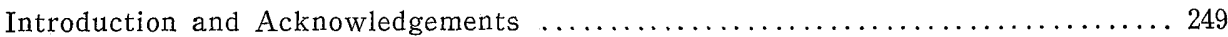

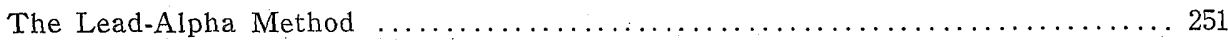

Preparation and Processing of Samples.............................. 251

Field Relation of the Source Rocks................................. 252

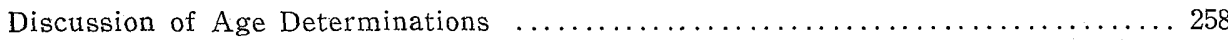

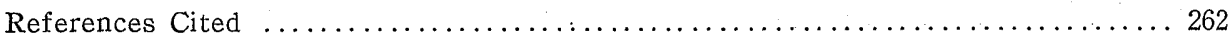

\section{Introduction and Acknowledgements}

Before the electronic theory as to the origin of dilute color of granite zircons (Tomita, 1954) can be established, much more data are needed on their ages. Thus,

Manuscript received May 1, 1965.

Yoshifumi Karakida: Department of Geology, Kyushu University. (Now at the Seinan Gakuin University, Fukuoka.)

Tôru Tomita : Department of Geology, Kyushu University. (Now at the University of Electronics, Fukuoka.)

David Gottfried, T.W. Stern, and H.J. Rose, Jr.: U.S. Geological Survey. 


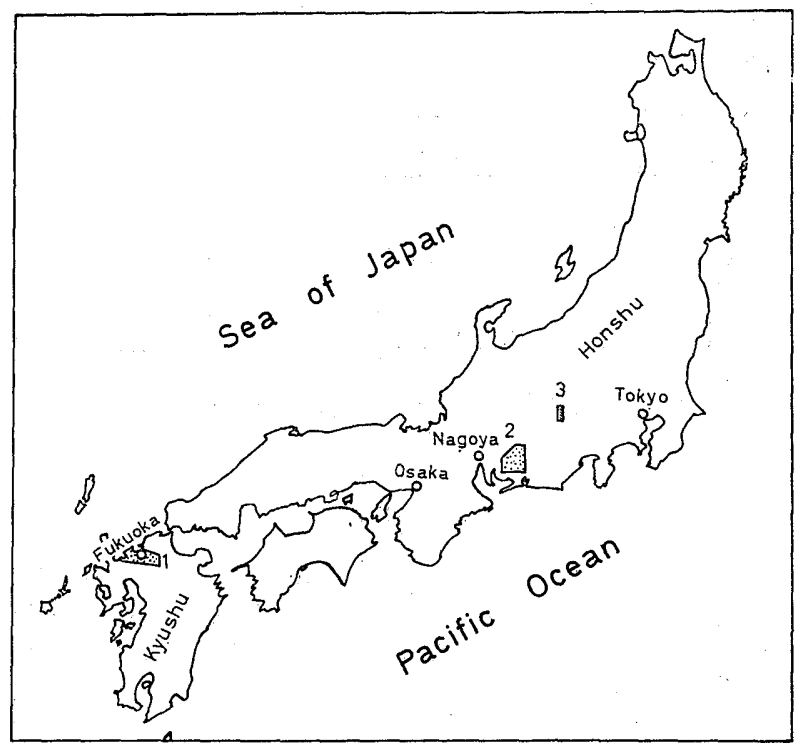

Fig. 1. Map showing location of the areas dealt with in the present study.

1. Fukuoka area; 2. Eastern Aichi district; 3. Takato area.

for accumulating the knowledge of zircon ages from granitic rocks in Japan, the leadalpha method was used. Though not so accurate and precise as isotopic methods, the lead-alpha method, which is rapid and relatively simple, can supply much useful information on various fields of geologic problem.

Samples of zircon and monazite were separated from granitic rocks of the Fukuoka area, North Kyushu, and of the eastern Aichi district and the Takato area, Central Japan, the latter two belonging to the Ryoke belt (Fig. 1). Zircon and monazite samples, except Z-3 (Table 1-2), from the eastern Aichi district were concentrated by SAKAI and his coworkers, and the separation of other samples and purification of all the samples used for dating were done by KARAKIDA. The age determinations were made by the laboratory staffs of the U.S. Geological Survey. One of the writers, TOMITA, is responsible both for the correlation of granitic rocks from the eastern Aichi district (Fig. 3) and for writing of this paper.

This is the first paper in Japan dealing with the lead-alpha ages of zircons and monazites from granitic rocks, and the results are believed to be satisfactory for reconnaissance purposes.

We are indebted to Professor E. SAKAI and his coworkers of Aichi Gakugei University for providing the samples of zircon and monazite from the eastern Aichi district. Professor T. MAtsumoto of the Department of Geology, Kyushu University, with great generosity of time and trouble, contributed much in discussion on the time classification of the Cretaceous period.

This work was partly financed by the Grant in Aid for Scientific Researches from the Ministry of Education, Japan. 


\section{The Lead-Alpha Method}

The age determinations dealt with in this paper were done by the lead-alpha method, generally: called LARSEN's method, which is useful for radioactive accessory minerals of granite, such as zircon and some monazite, whose non-radiogenic lead content is sufficiently low. This method involves only a radiometric analysis for the parent uranium and thorium and a spectrochemical analysis of the accumulated lead, so that it is rapid and relatively simple.

The lead content in this paper was determined by Rose and WoRTHING by a new method (ROSE and STERN, 1960), which is an improvement on the earlier one (WARING and WORTHING, 1953), and the results of 21 determinations (Table 1) show an average deviation of 5 per cent from isotopic dilution and chemical values.

The alpha activity was measured by a thick-source alpha-counting method, the accuracy of this measurement being believed to be \pm 5 per cent.

The lead-alpha ages were calculated from the following two equations:

$$
\mathrm{t}=\frac{\mathrm{c} \mathrm{Pb}}{\alpha}
$$

where $t$ is the calculated age in millions of years, $c$ is the constant based upon the $\mathrm{Th}: \mathrm{U}$ ratio given below, $\mathrm{Pb}$ is the lead content in parts per million, and $\alpha$ is the alpha counts per milligrams per hour.

$$
\mathrm{T}=\mathrm{t}-1 / 2 \mathrm{kt} \mathrm{t}^{2}
$$

where $T$ is the age in millions of years corrected for decay of uranium and thorium, and $\mathrm{k}$ is a decay constant based upon the Th: $U$ ratio. The following constants were used :

\begin{tabular}{|l|c|c|c|}
\hline Mineral & Assumed Th:U ratio & $\mathrm{c}$ & $\mathrm{k}$ \\
\hline Zircon & 1 & 2485 & $1.56 \times 10^{-4}$ \\
Monazite & 25 & 2085 & $0.65 \times 10^{-4}$ \\
\hline
\end{tabular}

These determinations described above have been carefully monitored and the results (Table 1) are believed to be satisfactory for reconnaissance purposes.

Now, the assumption of LARSEN and others (1952) that the lead in zircon is mainly of radiogenic origin is based on the principles of crystal chemistry. Thus, $\mathrm{Pb}^{2+}$ is too large $(1.32 \mathrm{~A})$ to substitute for $\mathrm{Zr}^{4+}(0.87 \mathrm{~A})$. On the other hand, the ionic radii of $\mathrm{K}^{+}$ (1.33A) and $\mathrm{Pb}^{2+}$ are virtually identical, and it would seem that during crystallization of a magma, lead would be captured in the potassium minerals, mainly orthoclase and biotite.

Most of many isotopic analyses reveal that, though with some notable exceptions, zircon is low (less than 10\%) in original lead content.

\section{Preparation and Processing of Samples}

The rock samples (either fresh or more or less weathered) were crushed with a stamp crusher to pass through a 50 -mesh sieve $(0.279 \mathrm{~mm}$ opening). The grinding 
equipment and sieve were carefully cleaned before and after each treatment. Heavy minerals were repeatedly concentrated by agitating the mixture of rock-powder and water in a large beaker, followed by the washing of lighter minerals away from the beaker. After removing magnetite with a horseshoe magnet, the heavy residue was gently boiled with concentrated hydrochloric acid for about 10 minutes and then washed with water. If pyrite was present, the residue was again boiled with concentrated nitric acid for about 10 minutes. Individual crystals among the non-magnetic fractions separated with a Franz isodynamic separator were picked out by hand (KARAKIDA, 1961, p. 62-63).

Thus, the samples used for the age determinations are either fractions of larger grains carefully picked out from the zircon concentrates or sized fractions of $50-250$ mesh size.

Our zircon samples have undergone some chemical leaching by weathering and by the $\mathrm{HCl}$ and $\mathrm{HNO}_{3}$ treatment. As pointed out in the previous paper (GoTTFRIED and others, 1959 , p. 37-41), it is unlikely that such leaching and difference in crystal size have serious effect on the zircon age.

\section{Field Relation of the Source Rocks}

\section{Fukuoka Area}

North Kyushu is composed mainly of Permian-Carboniferous sediments (metamorphosed and non-metamorphosed), Cretaceous formations, granitic intrusives, and Paleogene coal-bearing formations. The granitic intrusives are divided according to geological relationship, lithological feature, and characters of accessory zircons into ten or more units (MATSUMOTO, 1951; KARAKIDA, 1952). Though seven of these granite units are found in the area in question (Fig. 2), four of them were used in this study.

The Itoshima granodiorite is intruded either concordantly to sub-concordantly or partly discordantly into the Sangun metamorphic rocks, which are composed mainly of low-grade crystalline schists.

The Kitazaki granodiorite is intruded concordantly to sub-concordantly into the metamorphic rocks in the south-western part of the mass, but at the north-eastern margin intruded discordantly into the folded strata of early Cretaceous age (Kwanmon group) (MATSUMOTo, 1954, p. 154-176). In the conglomerates of the formation have commonly been found pebbles of sedimentary and low-grade metamorphic rocks, but not granitic and high-grade metamorphic rocks.

The Asakura granodiorite is a sub-concordant intrusion in the Sangun metamorphic rocks.

The Sawara granite is intruded discordantly into all the rocks mentioned above.

The Kitazaki, Asakura, and Sawara masses are unconformably overlain by the coal-bearing sediments of Paleogene age (Matsushita, 1949).

\section{Rock characters}

Itoshima granodiorite $(Z-12)$ : Most of the rocks are moderately coarse-grained and schistose, commonly containing basic inclusions. 


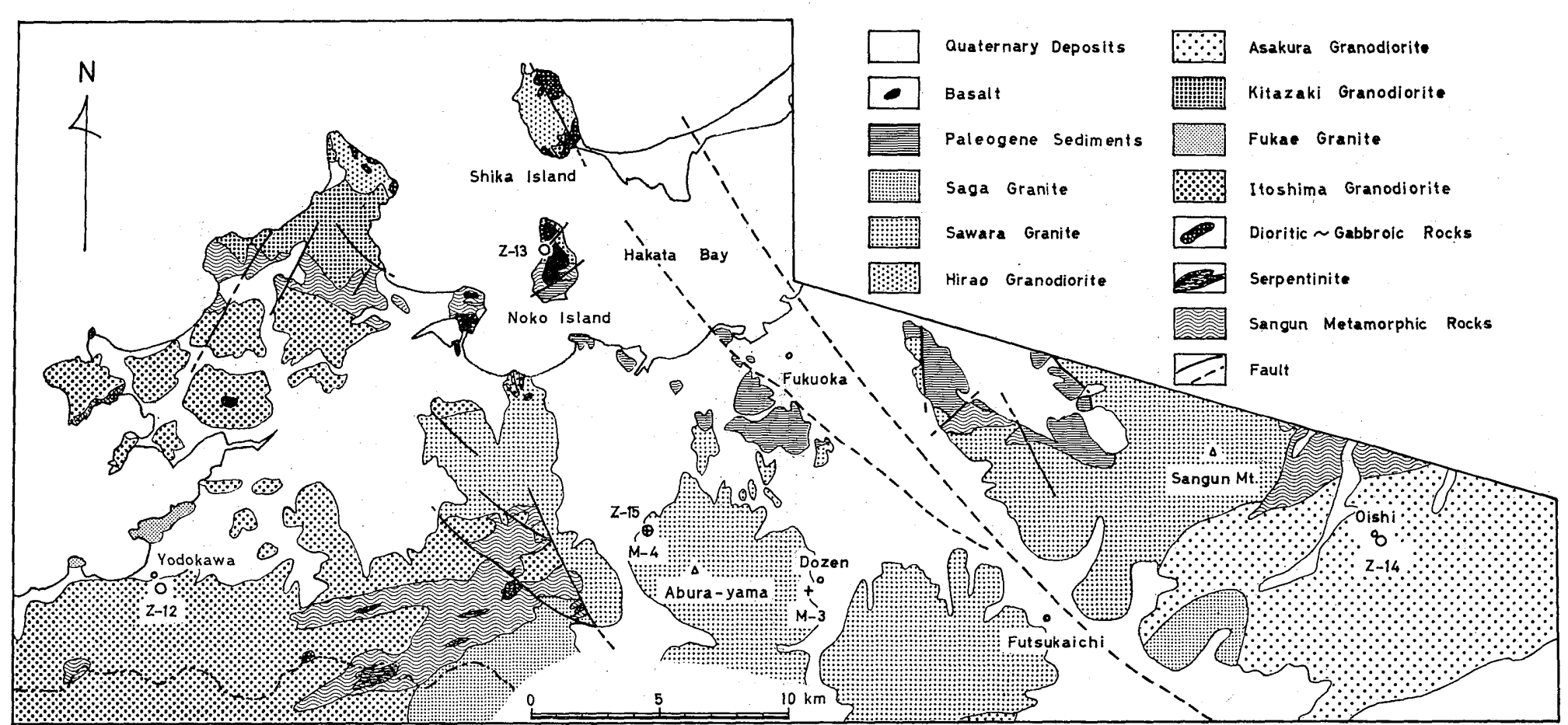

Fig. 2. Geologic map of the Fukuoka area. (After the geologic map of Fukuoka Prefecture, 1953 ; partly modified by KARAKIDA.) 
Kitazaki granodiorite $(Z-13)$ : The rock is characterized throughout the mass by the presence of purplish feldspars, and irregularly distorted large flakes of biotite, and by the intimate association of lamprophyre and tourmaline aplite. Schistose structure is well developed in the south-western part of the mass, but not towards the northeastern margin.

Asakura granodiorite (Z-14): The bulk of the rock is coarse-grained and massive, and contains conspicuous porphyritic hornblende and basic inclusions.

Sawara granite $(Z-15, M-3$, and $M-4)$ : The rock is moderately coarse-grained and massive, though in places has a linear structure. It carries varying amounts of porphyritic potassic feldspar and little dark inclusions.

\section{Eastern Aichi District}

Eastern Aichi district, Aichi Prefecture, Central Japan (Fig. 1), is composed mainly of the Ryoke granitic intrusives and associated metamorphic rocks (Fig. 3). According to KOIDE (1958), they are classified into the older and younger granodioritic intrusives and related metamorphic rocks as follows:

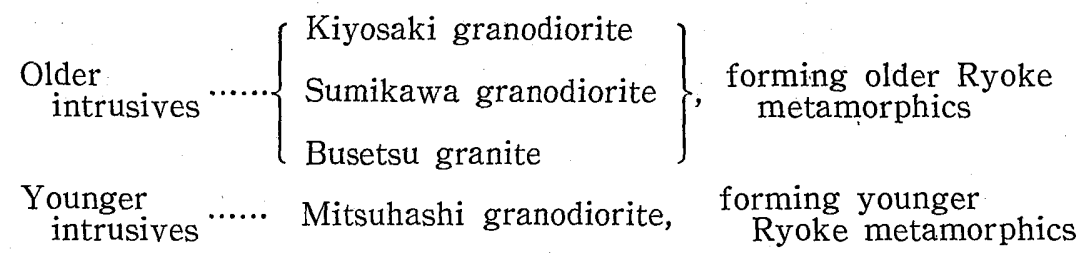

On the other hand, SAKAI and his coworkers, who have patiently engaged for many years in the confirmation of the sequence of intrusion in this district depending upon the characters of accessory zircons under the guidance of TomiTA, established the following general sequence (written communication):

$$
\begin{aligned}
& \text { Kranosaki } \longrightarrow \text { Mitsuhashi } \longrightarrow \text { granodiorite } \longrightarrow \text { granite } \\
& \text { Asuke (Sumikawa) granodiorite }
\end{aligned}
$$

\section{Rock characters}

The Asuke (Sumikawa) granodiorite (Z-4): According to KoIDE (1958), the rocks of this group are predominantly granodioritic in composition, coarse-grained, remarkably schistose, frequently characterized by the presence of porphyritic microcline and plagioclase, and commonly contain basic inclusions.

Mitsuhashi granodiorite $(Z-1, Z-2$, and $Z-3)$ : This group consists of coarse-grained rocks with varying schistose structure, containing abundant basic inclusions. According to KOIDE (1958), the most predominant type is granodiorite.

Busetsu granite $(\mathrm{M}-1$ and $\mathrm{M}-2)$ : It is generally fine-grained and massive, and characterized by the presence of muscovite and abundant monazite. 


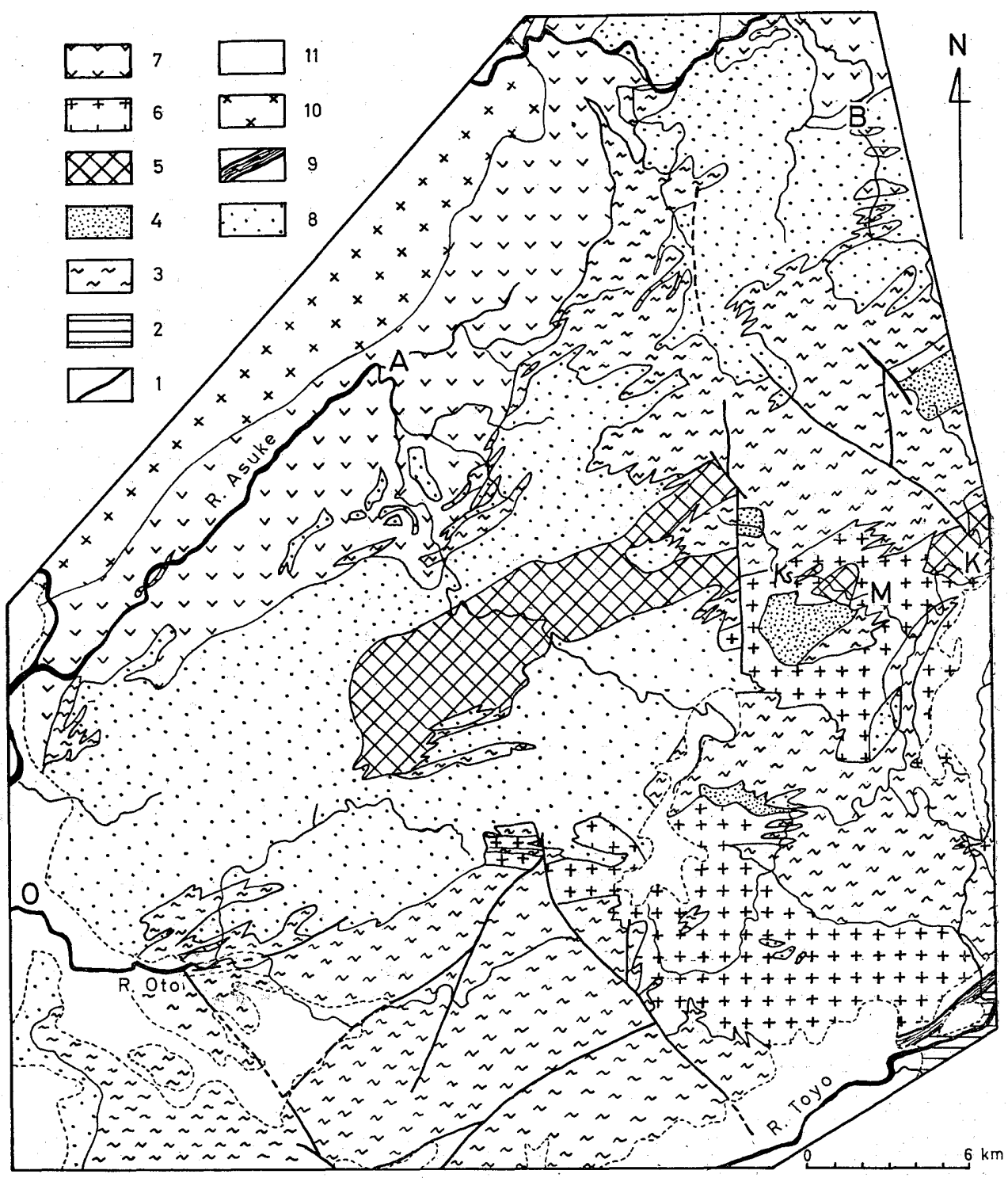

Fig. 3. Simplified map of the eastern Aichi district, Aichi Prefecture, compiled by KaRAKIDA and Tomita. Based on the works of KoIDE (1958), KIYONo and IsHII (1926), Ishil (1927), SAito (1952), and Nôtomi (1930).

1. Fault, 2. Sambagawa metamorphic rocks, 3. Ryoke metamorphic rocks; 4. Metamorphosed basic igneous rocks, 5. Kiyosaki granodiorite, 6. Mitsuhashi granodiorite, 7. Asuke (Sumikawa) granodiorite, 8. Busetsu granite, 9. Crushed rocks along the Median tectonic line, 10. Unclassified granitic rocks, 11. Neogene and y.ounger deposits.

A: Asuke, B: Busetsu, K: Kiyosaki, Ks: Kasaishima, M: Mitsuhashi, O : Okazaki. 


\section{Takato Area}

Takato Town and its adjacent country on the east, Nagano Prefecture, Central Japan (Fig. 1), has been repeatedly investigated by many geologists and petrologists in order to work out a puzzling problem concerning the origin of the "Kashio gneiss" which typically occurs along the Median tectonic line. This tectonic line divides this area into two major geologic belts: one is the Sambagawa belt consisting of various crystalline schists on the east and the other is the Ryoke belt consisting of metamorphic and granitic complex on the west (Fig. 4).

As clearly seen in Figure 4, the Ryoke belt in this area can be subdivided into five petrographical zones (HASHIMoTo, 1957; HAYAMA, 1960; KARAKIDA and TOMITA, 1957): they are, from east to west, Kashio mylonite, Hiji granodiorite, Osafuji quartz diorite, Ryoke gneiss, and Takato quartz diorite.

The Kashio mylonite is classified into six rock types according to the degree of protoclastesis. Broadly speaking, there is a general tendency that the more intensely mylonitized types occur in a zone closest to the Median tectonic line. Between the Kashio mylonite and the Hiji granodiorite there may be a transitional zone, a few tens of meters wide consisting of thin layers of the Kashio rocks with a sign of weak protoclastesis and the Hiji rocks without crushed features.

The Osafuji quartz diorite is intruded into the Hiji granodiorite. The former becomes foliated and finer in grain size in a zone, about $300 \mathrm{~m}$ wide, adjacent to the latter mass.

The Takato quartz diorite forms a mass separated from other Ryoke intrusives. Accoding to HAYAMA (1960), however, the thermal-metamorphic effects on the Ryoke metamorphic rocks in contact with the quartz diorite suggests that this quartz diorite is younger than the Ryoke granitic rocks.

Basing upon the geological relationship mentioned above, the geologic units in this area may be arranged in the order of decreasing age as follows:

Ryoke metamorphic rocks,

Hiji granodiorite and Kashio mylonite,

Osafuji quartz diorite, and

Takato quartz diorite.

\section{Rock characters}

Kashio mylonite (Z-5 and Z-6): According to the degree of protoclastesis, this mylonite is classified into six types: I to VI. The Kashio mylonite I, most intensely mylonitized, is gray blue, very fine-grained, with flinty streaks, lenses, or layers. This type has been described by some authors as "Hälleflinta-like rock." Types II, III, and IV are moderately mylonitized rocks including the "typical porphyroid-like rocks" in previous literatures. They show porphyritic appearance owing to porphyroclasts of feldspar, hornblende, and biotite embedded in fine-grained schistose and gneissose matrix. Grain size and amount of the porphyroclasts and grain size of the matrix minerals decrease with increasing mylonitization. In the types $\mathrm{V}$ and VI, porphyritic feldspar and hornblende, rough ovoid in shape, predominate over the matrix. The latter type with less protoclastic effect closely resembles the Hiji granodiorite in 
appearance.

Hiji granodiorite $(Z-7$ and $Z-8)$ : The rocks range in composition from gabbroic to leucogranitic, but granodiorite and quartz diorite characterized by gneissose or layered structure are common, while massive type is also met with in places.

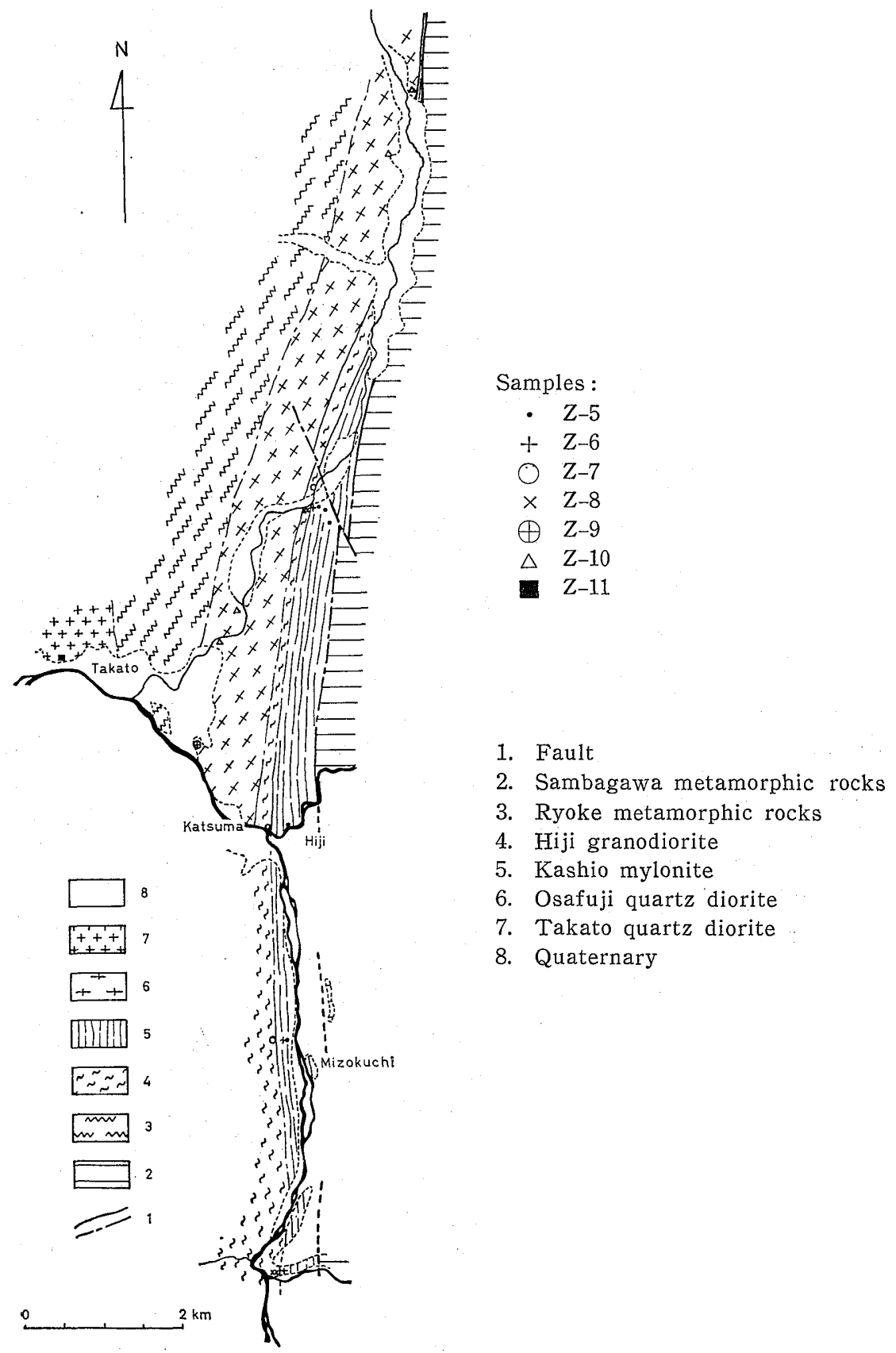

Fig. 4. Geologic map of the Takatofarea, Nagano Prefecture. 
Osafuji quartz diorite (Z-9 and Z-10): It is generally weakly schistose and coarsegrained with conspicuous reddish biotites. It becomes, however, foliated and finer in the zone near the Hiji granodiorite mass.

Takato quartz diorite (Z-11): It is medium-grained and massive with conspicuous. thick flakes of biotite and a little hornblende.

\section{Discussion of Age Determinations}

The results of our age determinations are shown in Table 1 and graphically in Fig. 5, together with those by other isotopic methods.

Comparisons between the lead-alpha and the K-Ar age obtained from the same granite masses in North Kyushu and Central Japan are given in Table 2. It is worthy of notice that there is a marked discrepancy between lead-alpha age and K-Ar ages of the Asuke (Sumikawa) granodiorite in contrast to the fair agreement in the two ages of the Itoshima granodiorite, Kitazaki granodiorite, Sawara granite, and Mitsuhashi granodiorite within the limits of error of the lead-alpha method. The Asuke (Sumikawa) biotite samples for the K-Ar age measurement (BANNo and MiLlER, 1961) are taken from the typical Sumikawa body defined by KOIDE (1958) in the northern part of the Dando-san area, while the zircons for the lead-alpha age measurement are from the south-western part of the Asuke body (Fig. 3), which is correlated with the Sumikawa granodiorite by TOMITA's correlation method (TOMITA, 1954). According to some authors (Ryoke Research Group, 1955), the Asuke granodiorite is geologically and lithologically correlated with the Inagawa granodiorite, typically developed near Iida, Nagano Prefecture, which is known to be 63 to $72 \mathrm{~m}$. y. old on the basis of biotite age determinations (ShibAtA et al., 1962). As yet there is no explanation for the above-mentioned inconsistency.

Another notice is paid to the facts that zircon and monazite from a single heavy concentrate (Ar 219) of the Sawara granite, though with widely different lead amounts and alpha activity, are in substantial agreement on ages, and that these ages are in complete agreement with monazite age of another concentrate (Ar 22) from the same rock mass (Table 1 ).

Now the results of our lead-alpha age determinations will be checked with geological evidences of time relation. In connection with this subject, it may be mentioned that KuLP's time scale (1961) and MATsumoto's time classification of Cretaceous period (personal communication, 1962) are used for reference.

In the Fukuoka area, about $90 \mathrm{~m}$. y. of the lead-alpha age for the Sawara granite is in accord with the inference that this granite is later in crystallization stage than the Masaki granite, Tagawa area, Fukuoka Prefecture, having $\mathrm{U}^{238}-\mathrm{Pb}^{206}$ age of $111 \pm 5 \mathrm{~m} . \mathrm{y}$. and $\mathrm{U}^{235}-\mathrm{Pb}^{207}$ age of $104 \pm 23 \mathrm{~m}$. y. for uraninite from pegmatite phase of the Masaki granite (INOUE and SATo, 1961), K-Ar age of $98 \mathrm{~m} . \mathrm{y}$. (SHIbATA, written communication, 1962), and chemical lead age of $96 \mathrm{~m}$. y. for cleveite from the pegmatite (KIMURA and IIMORI, 1937).

Massive facies of the Kitazaki granodiorite is seen intruding the Cretaceous Kwanmon group on the north-eastern margin of the mass, while in the south-western 


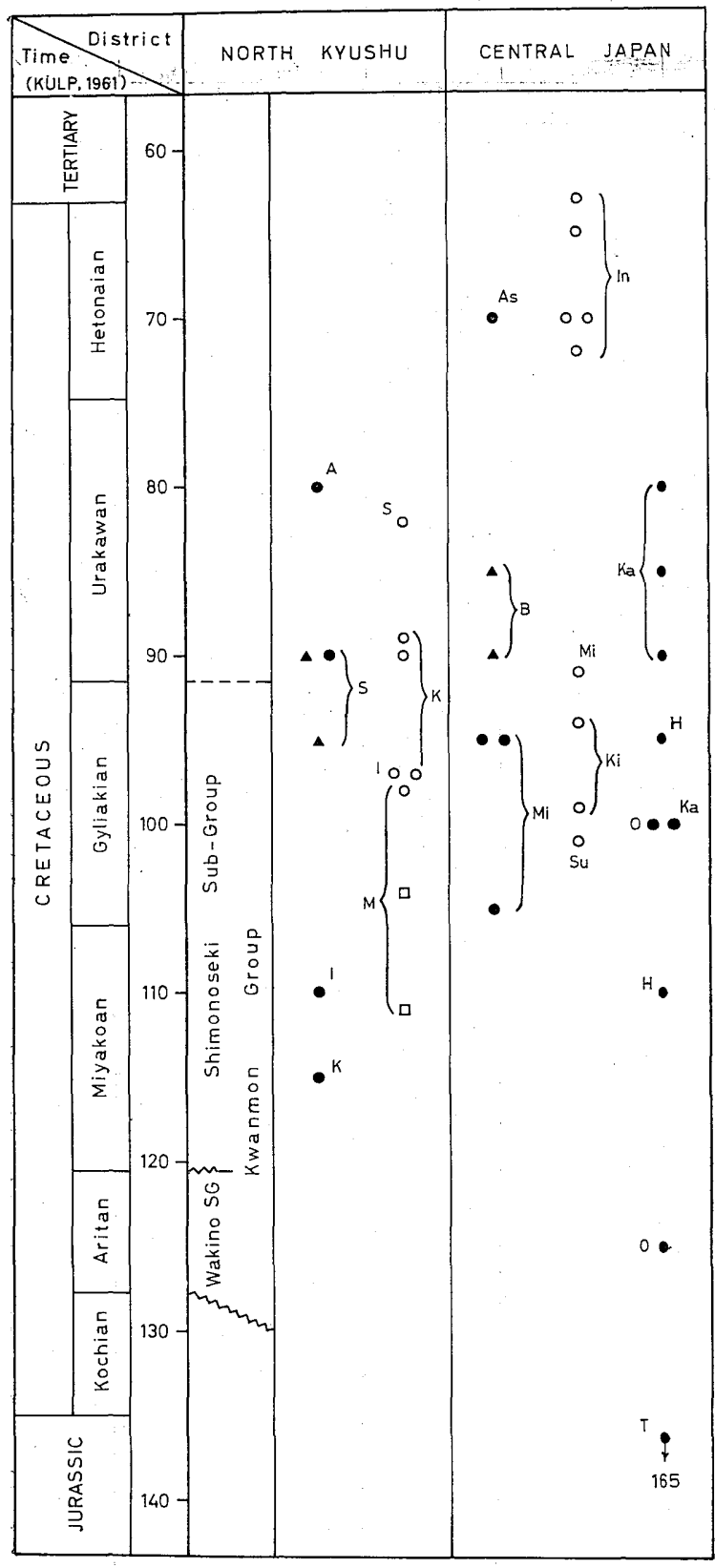

Legend :

A) Lead-alpha age (Zircon)

O $\mathrm{K}$-Ar age (Biotite)*

$\square \mathrm{U}-\mathrm{Pb}$ age (Uraninite)**

Abbreviation :

A, Asakura GD

As, Asuke GD

B, Busetsu Gr

$\mathrm{H}, \mathrm{Hiji}$ GD

I, Itoshima GD

In, Inagawa GD

K, Kitazaki GD

$\mathrm{Ka}$, Kashio mylonite

$\mathrm{Ki}$, Kiyosaki GD

M, Masaki Gr

Mi, Mitsuhashi GD

O, Osafuji QD

S, Sawara Gr

Su, Sumikawa GD

T, Takato QD

Fig. 5. Zircon, monazite, biotite, and uraninite ages from the granitic intrusives of North Kyushu and Central Japan.

* Banno and Miller, 1961; Miller et al., 1961; Shibata and Karakida, 1965; SHibAta et al., 1962.

** INoue and SATo, 1961. 
Table 1. Age determinations on granitic rocks from North Kyushu and Central Japan

\begin{tabular}{|c|c|c|c|c|c|}
\hline Sample & Rock & Mineral & $\alpha / \mathrm{mg} / \mathrm{hr}$ & $\mathrm{Pb}(\mathrm{ppm})^{* *}$ & $\begin{array}{l}\text { Age*** } \\
\text { (m. y.) }\end{array}$ \\
\hline \multicolumn{6}{|c|}{ (1) Fukuoka area, North Kyushu } \\
\hline Z-12 (Ud 302) & Itoshima granodiorite & Zircon & 261 & $10.5,12.5(11.5)$ & $110 \pm 10$ \\
\hline $\mathrm{Z}-13$ (Nk 16) & Kitazaki granodiorite & do & 79 & $3.6,3.9(3.7)$ & $115 \pm 15$ \\
\hline$Z-14(\mathrm{Dh} 86)$ & $\begin{array}{l}\text { Asakura granodiorite } \\
\text { (placer deposit) }\end{array}$ & do & 171 & $4.4,6.4(5.4)$ & $80 \pm 10$ \\
\hline$Z-15($ Ar 219) & $\begin{array}{l}\text { Sawara granite } \\
\text { (placer deposit) }\end{array}$ & do & 270 & $9.5,10.5(10.0)$ & $90 \pm 10$ \\
\hline M-3 (Ar 22) & do & Monazite & 3543 & 160 & $95 \pm 10$ \\
\hline M-4 (Ar 219) & do & do & 3816 & 165 & $90 \pm 10$ \\
\hline \multicolumn{5}{|c|}{$\begin{array}{l}\text { Mean age of the } 6 \text { samples } \\
\text { Standard deviation }\end{array}$} & $\begin{array}{l}97 \\
13\end{array}$ \\
\hline
\end{tabular}

(2) Eastern Aichi district, Central Japan

\begin{tabular}{l|c|c|c|c|c}
\hline Z-1 (T 283)* & Mitsuhashi granodiorite & Zircon & 150 & $5.8,6.8(6.3)$ & $105 \pm 10$ \\
Z-2 (T 332)* & do & do & 358 & $14,14(14)$ & $95 \pm 10$ \\
Z-3 (Dd 10) & do & do & 120 & $4.1,4.9(4.5)$ & $95 \pm 10$ \\
Z-4 (T 512)* & $\begin{array}{c}\text { Asuke (Sumikawa) } \\
\text { granodiorite }\end{array}$ & do & 413 & $10.5,12.5(11.5)$ & $70 \pm 10$ \\
M-1 (T IIA)* & Busetsu granite & Monazite & 3264 & 135 & $85 \pm 10$ \\
M-2 (T III)* & do & 3166 & 135 & $90 \pm 10$ \\
\hline
\end{tabular}

(3) Takato area, Central Japan

\begin{tabular}{|c|c|c|c|c|c|}
\hline $\begin{aligned} Z-5 & (\operatorname{In} 9,10 \\
& 12,64 c, 194) *\end{aligned}$ & Kashio mylonite IV & Zircon & 148 & $4.9,5.6(5.2)$ & $90 \pm 10$ \\
\hline do & do & $\begin{array}{l}\text { do } \\
\text { (leached) }\end{array}$ & 117 & $3.4,4.6(4.0)$ & $85 \pm 10$ \\
\hline $\begin{aligned} & Z-6(\operatorname{In} 7,128 \\
&195) *\end{aligned}$ & Kashio mylonite $\mathrm{V}$ & Zircon & 130 & $4.9,5.6(5.2)$ & $100 \pm 10$ \\
\hline do & do & $\begin{array}{l}\text { do } \\
\text { (leached) }\end{array}$ & 137 & $4.1,4.4(4.2)$ & $80 \pm 10$ \\
\hline $\begin{aligned} & Z-7(\operatorname{In} 76,152 \\
&198) *\end{aligned}$ & Hiji granodiorite I & Zircon & 378 & $16,18(17)$ & $110 \pm 10$ \\
\hline $\begin{aligned} & \text { Z-8 }(\text { In } 122 a, 124 \\
& 143 b, 145, \\
&176)^{*}\end{aligned}$ & Hiji granodiorite II & do & 245 & $9.5,9.5(9.5)$ & $95 \pm 10$ \\
\hline$Z-9(\operatorname{In} 91)$ & Osafuji quartz diorite & do & 61 & $2.3,2.5(2.4)$ & $100 \pm 10$ \\
\hline $\begin{aligned} Z-10 & \text { (In 3, 5, } \\
& 101,111) *\end{aligned}$ & do & do & 64 & $\begin{array}{l}\text { 2. } 9,3.0,3.5,3.6 \\
\quad(3.2)\end{array}$ & $125 \pm 15$ \\
\hline $\mathrm{Z}-11(\operatorname{In} 17)$ & Takato quartz diorite & do & 77 & 4. $6,5.6(5.1)$ & $165 \pm 20$ \\
\hline \multicolumn{5}{|c|}{$\begin{array}{l}\text { Mean age of the } 9 \text { sample } \\
\text { Standard deviation }\end{array}$} & $\begin{array}{r}106 \\
26\end{array}$ \\
\hline
\end{tabular}

* Composite sample.

** Figures in parentheses are averages used in deriving the calculated ages.

*** Ages are rounded off to nearest $5 \mathrm{~m}$. y.

Note:. Errors quoted above are those due only to uncertainties in analytical techniques. 


\section{LOCATION OF SAMPLES (Table 1 continued)}

Z-1 Mitsuhàshi and its vicinity, about $36 \mathrm{~km}$ NNE of Toyohashi City, Aichi Prefecture

Z-2 Kiyosaki and its vicinity, about $4 \mathrm{~km}$ east of Mitsuhashi, Aichi Prefecture

Z-3 Kasaishima, about $4 \mathrm{~km}$ west of Mitsuhashi, Aichi Prefecture

Z-4 The basin along the lower stream of Asuke-gawa, about $13 \mathrm{~km}$ NNE of Okazaki City, Aichi Prefecture

Z-5 11 Takato area, about $10 \mathrm{~km}$ east of Ina City, Nagano Prefecture (shown in Fig. 4)

Z-12 Yodokawa, Nijo Village, about $28 \mathrm{~km}$ WSW of Fukuoka City, Fukuoka Prefecture

Z-13. West coast of Noko Island, Fukuoka City, Fukuoka Prefecture

Z-14 Oishi, about $13 \mathrm{~km}$ ENE of Futsukaichi Town, Fukuoka Prefecture

Z-15 North-west foot of Abura-yama Hill on the southern border of Fukuoka City, Fukuoka Prefecture

M-1 Area including the northern part of Okazaki City and its adjacent country on the northeast, Aichi Prefecture

M-2 Area including the southern part of Okazaki City and its adjacent country on the east, Aichi Prefecture

M-3 Dozen, about $10 \mathrm{~km}$ south of Fukuoka downtown, Fukuoka Prefecture

M-4 North-west foot of Abura-yama Hill on the southern border of Fukuoka City, Fukuoka Prefecture

Table 2. Comparisons of $\mathrm{Pb}-\alpha$ and $\mathrm{K}-\mathrm{Ar}$ ages

\begin{tabular}{|c|c|c|c|c|c|}
\hline \multirow{2}{*}{\multicolumn{2}{|c|}{ Source }} & \multirow{2}{*}{ Mineral } & \multicolumn{2}{|c|}{ Age (m. y.) } & \multirow{2}{*}{ Reference } \\
\hline & & & $\mathrm{Pb}-\alpha$ & $\mathrm{K}-\mathrm{Ar}$ & \\
\hline \multirow{3}{*}{ 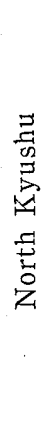 } & $\begin{array}{l}\text { Itoshima } \\
\text { granodiorite }\end{array}$ & $\begin{array}{l}\text { Zircon } \\
\text { Biotite }\end{array}$ & $110 \pm 10$ & $97 \pm 6$ & $\begin{array}{l}\text { This paper } \\
\text { SHIBATA and KARAKIDA, } 1965\end{array}$ \\
\hline & $\begin{array}{l}\text { Kitazaki } \\
\text { granodiorite }\end{array}$ & $\begin{array}{l}\text { Zircon } \\
\text { Biotite }\end{array}$ & $115 \pm 15$ & $\begin{array}{l}89 \pm 7 \\
90 \pm 8 \\
97 \pm 11\end{array}$ & $\begin{array}{l}\text { This paper } \\
\text { ShIBATA and KARAKIDA, } 1965\end{array}$ \\
\hline & $\begin{array}{l}\text { Sawara } \\
\text { granite }\end{array}$ & $\begin{array}{l}\text { Zircon } \\
\text { Monazite } \\
\text { Biotite }\end{array}$ & $\begin{array}{l}90 \pm 10 \\
90 \pm 10 \\
94 \pm 10\end{array}$ & $82 \pm 7$ & $\begin{array}{l}\text { This paper } \\
\text { ShIBATA and KARAKIDA, } 1965\end{array}$ \\
\hline \multirow{2}{*}{ 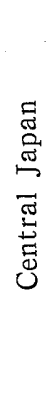 } & $\begin{array}{l}\text { Mitsuhashi } \\
\text { granodiorite }\end{array}$ & $\begin{array}{l}\text { Zircon } \\
\text { Biotite }\end{array}$ & $\begin{array}{r}95 \pm 10 \\
95 \pm 10 \\
105 \pm 10\end{array}$ & 91 & $\begin{array}{l}\text { This paper } \\
\text { BANno and Miller, } 1961\end{array}$ \\
\hline & $\begin{array}{l}\text { Asuke } \\
\text { (Sumikawa) } \\
\text { granodiorite } \\
\text { and allied } \\
\text { rocks }\end{array}$ & $\begin{array}{l}\text { Zircon } \\
\text { Biotite }\end{array}$ & $70 \pm 10$ & $\begin{array}{l}63 \\
65 \pm 3 \\
70 \\
70 \\
72 \\
101\end{array}$ & $\begin{array}{l}\text { This paper } \\
\text { Shibata et al., } 1962 \\
\text { BANNo and Miller, } 1961\end{array}$ \\
\hline
\end{tabular}

Decay constants of $\mathrm{K}^{40}$ :

(1) $\lambda_{\varepsilon}=0.585 \times 10^{-10} \mathrm{yr}^{-1}, \quad \lambda_{\beta}=4.76 \times 10^{-10} \mathrm{yr}^{-1}$ (BANNo and MilleR, 1961).

(2) $\lambda_{\varepsilon}=0.584 \times 10^{-10} \mathrm{yr}^{-1}, \quad \lambda_{\beta}=4.72 \times 10^{-10} \mathrm{yr}^{-1} \quad$ (ShiBATA et al., 1962 ; ShIBATA and KARAKIDA, 1965). 
part schistose facies including the 115-million-year-old rocks are not in contact with the Kwanmon group. Thus, a fruitfull discussion on the geological problem demands more data on the ages and relationship of the two different rock facies and the invaded Kwanmon group.

In addition, there is no explanation for the rather small value ( $80 \mathrm{~m}$. y.) obtained for the Asakura granodiorite which is intruded by the Masaki granite.

In the eastern Aichi district, the stratigraphic age of the granitic rocks is known to be pre-upper Miocene, and it is not possible to check our lead-alpha ages with stratigraphical evidence.

'The zircon age for the Takato quartz diorite $(165 \mathrm{~m} . \mathrm{y}$.) is significantly older than the mean age for the granitic rocks, what are known as " Ryoke granites," of this area. It should be stated in this connection that, according to HAYAMA's opinion (1960 p. 96), the Takato quartz diorite is one of "the post-Ryoke granitic rocks," but no Ryoke granitic rocks have been found in contact with the quartz diorite. Thus, the age of the Takato quartz diorite is worthy of further study.

In conclusion, our lead-alpha age determinations of granitic rocks in North Kyushu and Central Japan have given satisfactory results in that they are fairly consistent with the ages assigned in the stratigraphic evidence and with those obtained by other isotopic methods, though with some exceptions.

\section{References Cited}

Banno, Shohei, and A. Miller (1961): New data on the age of the formation of Ryoke and Sambagawa metamorphic belts. Kagaku (Science), 31, 144 (in Japanese).

Gottfried, David, H. W. JAFFe, and F.E. Senftre (1959): Evaluation of the lead-alpha (Larsen) method for determining ages of igneous rocks. U.S. Geol. Surv. Bull., 1097-A, $1-63$.

Hashimoto, Mitsuo (1957): On the basic plutonic rocks of Miwa and Inasato district, Nagano Prefecture, Central Japan. Bull. Nat. Sci. Museum, No. 40, 137-155.

Hayama, Yoshikazu (1960): Geology of the Ryoke metamorphic belt in the Komagane district, Nagano Prefecture, Japan. Jour. Geol. Soc. Japan, 66, 87-101.

INoue, Hideo, and Kazuo SATo (1961): Mode of occurrence and absolute age of uraninite from Ryuen mine, Fukuoka Prefecture. Jour. Jap. Ass. Min. Petrol. Econ. Geol., 46, 133-137 (in Japanese with English abstract).

Ishin, Kiyohiko (1927) : "Toyohashi." Exp. Text of Geol. Map of Japan, 1/75,000. Geol. Surv. Japan, 40p. (in Japanese with English abstract).

KARAKIDA, Yoshifumi (1952): Geological relations between granitic rocks in North Kyushu (abstract). Jour. Geol. Soc. Japan, 58, 277 (in Japanese).

- (1961): Zircon overgrowths in the Ryoke metamorphic zone of the Yanai area, Southwest Japan. Mem. Fac. Sci., Kyushu Univ., Ser. D (Geology), 10, 59-72.

-_-, and Tôru Tomita (1957): Rocks and accessory zircons of the so-called Kashio gneiss (abstract). Jour. Geol. Soc. Japan, 63, 439-440 (in Japanese).

Kimura, Kenjiro, and Takeo Irmori (1937): Chemical studies of the rare element-bearing minerals from the Orient. Part 26. On the uraninite and monazite from Amaki Village, Fukuoka Prefecture. Jour. Chem. Soc. Japan, 58, 1135-1143.

KiYono, Nobuo, and Kiyohiko Ishir (1926) : “Asuke." Exp. Text of Geol. Map of Japan, 1/75,000. Geol. Surv. Japan, 49p. (in Japanese with English abstract).

Kolde, Haku (1958): Dando Granodioritic Intrusives and their Associated Metamorphic Complex. Jap. Soc. Promotion Sci., Tokyo, 311p. 
Kulp, J.L. (1961): Geologic time scale. Science, 133, 1105-1114.

Larsen, E.S., Jr., N. B. KeEvil, and H.C. Harrison (1952): Method for determining the age of igneous rocks using the accessory minerals. Bull. Geol. Soc. Am., 63, 1045-1052.

Matsumoto, Tatsuro (1951): An outline of the fundamental geologic structure in North Kyushu and West Chugoku. Sci. Rep., Kyushu Univ., Geology, 3, 37-48 (in Japanese). (Chairman) (1954): The Cretaceous System in the Japanese Islands. Jap. Soc. Promotion Sci., Tokyo, 324p.

Matsushita, Hisamichi (1949): A summary of the Palaeogene stratigraphy of northern Kyushu. Mem. Fac. Sci., Kyushu Univ., Ser. D (Geology), 3, 91-107.

Miller, J. A., Fumiko Shido, Shohei Banno, and Seiya Uyeda (1961): New data on the age of orogeny and metamorphism. Jap. Jour. Geol. Geog. 32, 145-151.

Nôtomı, Shigeo (1930): “Shidara." Geol. Map of Japan, 1/75,000. Geol. Surv. Japan.

Rose, H. J., Jr., and T.W. STERN (1960): Spectrochemical determination of lead in zircon for lead-alpha age measurements. Am. Mineral., 45, 1243-1256.

Ryoke Research Group (1955): Geological collaboration on the Ryoke metamorphic zone, Japan. Earth Science, No. 25, 1-3 (in Japanese with English abstract).

SAito, Masatsugu (1952): “Mikawa-Ono." Geol. Map of Japan, 1/50,000. Geol. Surv. Japan.

Shibata, Ken, and Yoshifumi Karakida (1965): Potassium-argon ages of the granitic rocks from the northern Kyûshû. Bull. Geol. Surv. Japan, 16 (in press).

- J.A. Miller, Naotoshi Yamada, Kiyoo Kawata, Masaro Murayama, and Masao KATADA (1962): Potassiumargon ages of the Inagawa granite and Naegi granite. Bull. Geol. Surv. Japan, 13, 317-320 (in Japanese).

TомiтA, Tôru (1954): Geologic significance of the color of granitic zircon, and the discovery of the pre-Cambrian in Japan. Mem. Fac. Sci., Kyushu Univ., Ser. D (Geology), 4, 135-161.

WARING, C. L., and H.W. WORTHING (1953): A spectrographic method for determining trace amounts of lead in zircon and other minerals. Am. Mineral., 38, 827-833. 